\title{
ALGEMEENE VERGADERING
}

\section{VAN LEDEN VAN HET KONINKLIJK INSTITUUT VOOR DE TAAL-, LAND- EN VOLKENKUNDE VAN NEDERLANDSCH INDIE,}

\section{TE PARAMARIBO}

in het lokaal der koloniale bibliotheek op Vrijdag 21 Februari 1868.

Tegenwoordig: de heeren Mr. E. A. van Emden (Voorzitter), F. Carstairs, J. F. A. Cateau vau Rosevelt, A. M. Coster, Mr. G. J. A. Bosch Reitz, Ds. S. van Dissel, Dr. J. J. Juda, A. H. de Granada, Dr. J. Sander en S. Abeudanou.

De Voorzitter, Mr. E. A. van Emden, opent de vergadering.

De notulen van het verhandelde in de vorige algemeene vergadering worden gelezen en goedgekeurd.

De Voorzitter zet de redenen uiteen, waarom deze bijeenkomst niet op het in de vorige vergaderung vastgestelde tijdstip gehouden is en schrijft die hoofdzakelijk toe aan de afwezigheid van vele leden en voornamelijk aan het eerst laat ingekomen antwoord van het Bestuur des Instituuts op een dezerzijdsch schrijven omtrent eenige in de vorige algemeene vergadering geopperde vragen, waaromtrent hị thans, wat deze en andere hoofdpunten betreft door voorlezing en mondelinge inlichtingen mededeeling doet.

Voorts brengt hij ter kennis dat het Instituutsjaar veranderd is, zoodat het thans met primo Januari is aangevangen en met ultimo December eindigt, weshalve van de leden over het toen loopende jaar (1867) slechts $f$ 8.- voor contributie zal worden gevorderd. Aangezien de heer P. J. Eyken Sluijters weigerachtig is gebleven om de achterstallige contributie te voldoen, hebben 
commissarissen van dien heer niets ingevorderd, aangezien zij geeu recht meenden te hebbeu om de contributie slechts gedeeltelijk te innen.

De Voorzitter stelt aan de orde de onderwerpen Kolonisatie en Immigratie, waarvau de bespreking in deze vergadering was vastgesteld. Aangezien thans de kolonie in een toestand verkeert dat haar voortbestaan van eene spoedige en voldoende immigratie afhankelijk is, die meer dan immer te voren erkend wordt de levensvraag voor Suriname te zijn, zoo geeft hij der vergadering in bedenking op dezen avond vooral dit laatste punt te behandelen.

De heer J. Sander zegt, dat hij om tot eene practische oplossing van het vraagstuk: kolonisatie van Suriname met Europeanen te geraken, eene zaak die hem zooveel belang inboezemt, inlichtingen heeft ingewonnen bij eenige boeren, die van de Europeesche kolonisatie te Groningen aan de Saramacca afkomstig en thans in de nabijheid vau Paramaribo gevestigd zijn. Deze hebben op de vraag of naar hun gevoelen eene kolonisatie met Europeanen alhier slagen zou, eenparig geantwoord: ja, maar niet op de wijze zooals zij vroeger heeft plaats gevouden. Volgens hen zou het best zijn, indieu Europeesche boeren zich bij de reeds hier gevestigde landbouwers aansloten; zelfs zou het hun aangenaam zın wanneer zich een vijftigtal landgeuooten bij hen wilden nederzetten.

De gezondheidstoestand bij de om de stad gevestigde boeren is thans vrij voldoende; de geboorte bedraagt iets meer dan de sterfte. De meeste ziekten die onder hen voorkomen ziju koortsen, die hoofdzakelijk aan de groote vochtigheid van het terrein zijn toe te schrijven; hoe meer dit wordt droog gelegd eu bebouwd, des te gezonder het worden zal. De tegenwoordige waterloozingen laten zeer veel te wenschen over; maar deze kunnen verbeterd worden, hetwelk stellig het geval zal ziju indieu de landbouwende bevolking vermeerdert. $Z_{i j}$ verlangen dau ook sterk naar Europeesche landverhuizers, waarvan een vijftigtal in de streek waar zij wonen, een goed bestaan vinden z.ou. De kosten, die voor elken boer tot zijne vestiging vereischt worden, schatten zij op $f 3000$. - dat hun voorgeschoten zou moeten worden en in tien jaren kan worden terug betaald. Op de vraag hoedanig hume voeding is, werd geantwoord: dat 
deze niet slecht is; dat zij plantenvoedsel in overvloed hebben, terwijl wat dierlijk voedsel aangaat, zij gebruik maken van het beste soort Amerikaansch zoutvleesch, het zoogenaamde familiebeaf; ook levert de jagt nu en dan iets op.

$\mathrm{Hij}_{\mathrm{ij}}$ meent dat deze inlichtingen waarde hebben, omdat zij verkregen zijn van menschen, die alles uit de ervaring hebben geput.

De heer A. H. de Granada zegt dat hij eens bij de behandeling eener strafzaak in de gelegenheid is geweest om verschillende boerenfamiliëu te bezoeken. Daarbij heeft hem één tooneel zoodanig getroffen, dat hem dit steeds in herinnering gebleven is. Over het algemeen had hij bevonden, dat de huisvesting der boeren slecht en ook veel te klein is: een veel te groot antal menschen waren in een klein vertrek als het ware opeengepakt. Het komt hem voor dat de hoofdzaak bij eene kolonisatie niet alleen gelegen is in de voeding maar ook in de goede huisvesting; zal eene kolonisatie met Europeanen alhier ooit gelukken, dan moeten z. i. de woningen ruim en goed geventileerd zijn. Hij gelooft dat dit te veel wordt over het hoofd gezien en dat Europesche kolonisatien dikwijls mislukt zijn, omdat te veel menschen in eene te beperkte en slecht geventileerde ruimte waren opeengehoopt.

Het gesprokene geeft slechts den indruk weêr, die toen bij hem is te weeg gebracht maar waarin hij door nadenken versterkt is; hij verwijst overigens naar een geneeskundige, die deze vergadering bijwoont en het feit als deskundige constateren kan.

De heer Dr. J. J. Juda wil met een enkel woord te kennen geven, dat hij het in het geheel uiet eens is met Dr. Dumontier, wiens gevoelen betrekkelijk kolonisatie van Europeanen in een tropisch klimaat hij uit de zoo even voorgelezen notulen der vorige vergadering heeft leeren kennen. Hij moet toegeven dat waar zij tot dusverre beproefd is, zij steeds is mislukt, maar hij vraagt: is de oorzaak dier mislukking naar behooren opgegeveu? Zoo verre hij na kan gaan was deze steeds te vindeu in gebrek aan de noodige voorzorgen en in bijkomende noodlottige omstandigheden, maar zij kan geenszins aan het klimaat worden toegeschreven. Als een voorbeeld wil hij slechts aanhalen de kolonisatieproef aau de Saramacca, dewijl deze van algemeene bekendheid is. Toen de boeren in de kolonie kwamen, 
was er hoegenaamd niets voor hen gereed gemaakt, er was volstrekt geen zorg voor hunne outvangst gedragen. Op het meest moerassige deel van de oevers der Saramacca had men in der haast eenige ellendige hutten opgeslagen, waarin de menschen als het ware opeengehoopt werden; voor geneeskundige verpleging was hoegenaamd geene zorg gedragen; de voeding was slecht. Kon het nu wel anders als dat onder die omstandigheden eene verschrikkelijke ziekte ontstond, die een groot gedeelte der kolonisten ten grave sleepte, en van anderen den moed en het vertrouwen op een goeden uitslag ten eeneumale vernietigde? Het is niet aan twijfel onderhevig dat door zulke slecht genomen maatregelen steeds alle kolonisatiën zullen mislukken.

$\mathrm{Hij}_{i j}$ is overtuigd, dat Europeanen bij den landbouwarbeid in Suriuame gezond kumnen blijven, mits in den beginne alle noodige voorzorgen genomen worden. In de eerste plaats moet gelet worden op de woningen; deze moeten ruim, wel geventileerd en eenigszins boven den vochtigen bodem verheven zijn. Vervolgens zorge men, dat de werklieden niet op het heetst van den dag naar den arbeid gaan, maar des morgeus vroeg, wanneer het nog koel is; hij houdt den vroegen morgenstond voor zeer gezoud en als den besten tijd van den dag voor elke soort van arbeid. Ook zorge men voor eene doelmatige voeding. En wanneer nu dat alles in acht genomen wordt, dan gelooft hij dat eene kolonisatie met Europeesche boeren zeer wel gelukken zal. Wel is waar zullen zij aanvankelijk voor de zware kultuur, zooals bij die van suiker, niet gebezigd kumnen worden, maar in den beginne kumnen zij lichteren veldarbeid doen en zullen zoo laugzamerhand meer geschiktheid bekomen tot het verbouwen van stapelproducten, waarvoor zwaardere arbeid vereischt wordt.

Hij erkent dat hij vroeger boereu en hunne kinderen gezien heeft, die er zeer slecht uitzagen; maar hij kan bepaaldelijk zegren dat hune ziekelijkheid meestal was toe te schrijven aan deze twee oorzaken: slechte voeding en gebrekkige geneeskundige behandeling. Immers wat ziet men meestal bij die lieden ingeval van ziekten gebeuren? In plaats van bij het ontstaan der ziekte den geneesheer te roepen, wachten zij daarmede tot het veelal te laat is. Hieraan is dikwijls het gevaarljk en slepend karakter van vele ziekten toe te schrijven. Dat het hier zoo ongezond zou zijn, moet hij ten eenemale ontkennen.

Hy heeft in Europa veel gevaarlijker ziekten gezien dan die 
hier gewooulijk voorkomen en gelooft bijna, dat het daar ongezonder dan in Suriname is.

De heer Mr. G. J. A. Bosch Reitz vraagt den vorigen spreker of naar zijn gevoelen Europeanen van noordelijke streken en hunne afstammelingen hier op den duur dezelfde krachten zullen behouden als in Europa.

De heer Dr. Juda zegt dat zij misschieu wel niet dezelfde krachten zullen blijveu behouden die zij in Europa hadden, maar dat zulks in dit vruchtbare land ook niet zoozeer noodig is. Hij meent dat wanneer zij slechts de helft hunner krachten overhoudeu, dit nog altijd voldoende zal zijn om een behoorlijk bestaan uit den landbouw te trekken.

De heer Mr. Bosch Reitz vraagt of de kinderen der kolonisten, die hier geboren zijn, niet veel zwakker dau de ouders zijn?

De heer Dr. Juda. Op de vorige aan hem gerigte vraag moet hij antwoorden: ja, maar hij wijt dit geheel aan de vroeger door hem opgegeven algemeene oorzaken van het mislukken van Europeesche kolonisatieu. Hij meent dat dit verbeteren zal, wanneer gezorgd wordt niet alleen voor goede huisvesting maar ook voor eene krachtige voeding. Het voedsel moet naar zijne meening bestaan uit: gezouten vleesch, wild, visch, boonen, erwten, brood enz.

De Voorzitter zegt dat naar zijne meening nog meer dan dit alles voor het welslagen van kolonisatie gevorderd wordt. Hij wijst op de goede voeding, die de Wurtembergsche kolonisten bij Kappler aan de Marowijne hadden; in weerwil deze goed was, is die kolonisatie toch mislukt.

De heer Granada zegt dat het hem aangenaam is betreffeude de kolonisatie aan de Marowijne eenige inlichtingen te kunneu geven. Hij had die in der tijd bezocht en heeft gezien, dat de gezondheid der kolonisten niets te wenschen overliet. $\mathrm{Zij}_{\mathrm{j}}$ ontvingen goed en krachtig voedsel en hadden goede woningen. Er werd geregeld gewerkt; maar, dit moet hịj er bij zeggen, zij werkten meestal in de schaduw. De heer Kappler zeide bij die gelegenheid, dat hij overtuigd was, dat zijue arbeiders in 
staat waren zonder hunne gezondheid te benadeelen vele soorten van arbeid op plantaadje te kunnen verrichten.

De heer S. Abendanon was het in de vorige vergadering niet eens met den heer Dumontier, doch vond het gewaagd verder te gaan en tegen een deskundige het woord te voeren. Thans evenwel, nu hij gehoord heeft dat een ander deskundige Dr. Juda evenmin de gevoelens van den heer Dumontier betrekkelijk eene kolonisatie met Europeesche landbouwers in Suriname deelt, zal hij de vrijheid nemen zijne denkbeelden betrekkelijk dat gewichtig vraagstuk eenigszins breeder uit een te zetten.

Hij wil nog een oogenblik stilstaan bij de kolonisatie aan de Saramacca, die in den loop van den avond reeds kortelijk besproken is. Hịj acht het van genoegzame bekendheid dat de keuze der individu's niet goed is geweest; dat er velen onder waren die geen eigenlijke boeren waren, maar menschen uit de heffe des volks, die tot een kolonisatie in Suriname geene geschiktheid bezaten. Dit was ook naar hị meent het geval met de kolonisatie aan de Marowijne. Wel kent hij een paar geschikte menschen, die daarvan afkomstig zij̣n, maar een groot gedeelte behoorde evenmin tot de landbouwende klasse als die van de Saramacca. Deze daadzaken, die door de vorige sprekers niet zijn aangevoerd, wil hij slechts aanstippen, omdat zij bepaaldelijk hebben medegewerkt tot het mislukken van beide nederzettingen.

De antecedenten der vorige kolonisatien hebben geleerd dat het geene gemakkelijke taak is alles voor de ontvangst wel voor te bereiden; hij gelooft dat dit voor eene kolonisatie in het groot hoogst moeilijk is, maar Spr. is het met Dr. Juda eens, dat zulks eene noodzakelijke voorwaarde van haar welslagen is. Hij is daarom op het oogenblik meer voor eene geleidelijke kolonisatie. Een groot aantal planters zouden op hunne plantaadjes Europeesche boeren en ambachtslieden kunnen gebruiken; hị is overtuigd dat zij in het jonge riet, bij fabriekarbeid, maar vooral bij de cacaokultuur goede diensten kunnen bewijzen. Wanneer slechts de noodige voorzorgen voor de ontvangst dezer menschen genomen worden, dan meent hij zal eene kolonisatie op die wijze tot stand gebracht niet kunnen falen goede uitkomsten te geven, mits men bv. geen barbiers aan de spade gaat plaatsen, mạar zich werkelijk tot landhouwers bepaalt. Ook 
hij is van gevoelen dat Europeanen des morgens vroegtijdig aan den arbeid behooren te gaan en dat zij op het heetst van den dag binnen 's huis of in de schaduw nog het een en ander kunnen doen. In Europa krijgt wel is waar het lichaam herstel zijner krachten door den winter, maar daarentegen is hier de arbeid zoo veel lichter, dat dit nadeel ruimschoots opgewogen wordt. Hij gelooft dat eene kolonisatie op het oogenblik niet denkbaar is om de eenvoudige reden dat de middelen daartoe ten eenenmale ontbreken. Maar eenmaal zal zịj gelukken, dit is voor de toekomst weggelegd en heeft men ook thans al de middelen niet, het staat aan ons om de goede zaak bevorderlijk te zijn door planters en landbouwers op het groot belang te wijzen dat zij bij eene kolonisatie met Europeesche boeren hebben.

Zoowel van kolonisatie als van immigratie hangt de toekonst der kolonie af; hij stelt dus voor om beide zaken niet afzonderlijk te behandelen, maar eene commissie te benoemen die deze vraagstukken onderzoekt en eeu geschrift of verslag samenstelt, dat daarover handelt.

De heer de Granada wil slechts een woord releveren, dat zooeven door den heer Abendanon is geuit. Heeft Spr. deze wel begrepen, dan zou een der redenen van mislukking der kolonisatie met Europeanen zijn, dat velen van hen geen landbouwers waren, of zooals de heer Abendanon zich kernachtig uitdrukte dat men een barbier aan de spade had geplaatst. Dit laatste is volkomen waar; het feit is hem bekend.

Om weder op de kolonisatie van de Marowijne terug te komen wil hij nog doen opmerken, dat de eerste bezending kolonisten, geschikte arbeiders waren; maar toen later een agent was aangesteld, werden als kolonisten uitgezonden menschen, die nimmer een spade hadden in handen gehad en het werk nog moesten leeren. Het bleek spoedig dat deze lieden voor het doel ongeschikt. waren en mede oorzaak zijn geweest dat de nederzetting verloopen is.

De heer de Bosch Reitz zegt in de meening te verkeeren dat de arbeiders aan de Marowijne, als houtwerkers en niet als landbouwers waren uitgezonden.

De Voorzitter geeft hetzelfde te kennen en voegt er bij dat 
in allen gevalle Albina nog geen bewijs oplevert dat eene kolonisatie met Europeesche landbouwers alhier gelukken zal en wel hoofdzakelijk omdat die nederzetting van te korten duur is geweest en Albina bijzonder gezond gelegen is. Hij gelooft integendeel dat Europeanen voor de stapelkultuur niet kunnen worden dienstbaar gemaakt, om de eenvoudige reden, dat het voor hen op den duur niet mogelijk is in de zon te arbeiden. Men heeft wel de vroege morgenuren als den geschiktsten tijd van den dag genoemd om-in het veld te arbeiden, maar daartegen kan hij als het gevoelen van andere deskundigen aanvoeren dat de vroege ochtendlucht niet gezond is wegens hare groote vochtigheid en de miasınata, die dan juist het ergste zijn.

De heer S. van Dissel zegt, dat hij het eens is met hen die beweren dat Europeanen in een heet klimaat goed kunnen aarden. Als een voorbeeld haalt hij Aruba aan. Dáár heeft de ondervinding van twee eeuwen geleerd, dat eene kolonisatie met Europeanen goed kan slagen. De kolonisten van Aruba zijn van Europeesche afkomst, zij zijn gezond en sterk, het zijn kerels als boomen. Zij werken den geheelen dag in de open lucht en zijn juist daardoor zoo gehard; terwijl hij hier nog bij kan voegen dat de bevolking sterk vermeerdert. Hij spreekt hier als ooggetuige en zegt dat dit een bewijs is, dat afstammelingen van Europeanen in een warm klimaat zeer gezond kunnen leven, en wanneer dit nu voor Aruba zoo is, waarom dan ook niet voor Suriname? Maar wat is het onderscheid? Hier leven de menschen bijna uitsluitend van bananen, dat als een slecht voedsel bekend is; dár bestaat de voeding hoofdzakelijk uit mais, schapen- en geitenvleesch, dat op Aruba in overvloed geteeld wordt. Zoolang hier van bananen wordt geleefd zal het nooit goed met de gezondheid gaan.

De heer A. M. Coster zegt, dat hij door zijne verschillende reizen in de binnenlanden dezer kolonie veel heeft gezien en betrekkelijk het klimaat ook veel ondervinding heeft opgedaan. Zoo heelt hij o. a. de Tampatiekreek bezocht, eene schoone streek, die voor kolonisatie wel geschikt zou zijn. Hij had daar het klimaat geheel anders gevonden dan in'de benedenlanden; immers terwijl het overdag zeer heet was, werd het daarentegen des nachts zoo koud, dat men de boter met een mes kon snij- 
den. Desniettegenstaande had hij het daar zeer gezond gevonden Zoo ook in Boven-Para. Daar wonen zooveel Europeanen die den geheelen dag in de zon zwaar moeten werken en toch gezond zijn; maar zij werken des morgens van 6 tot 10 en des namiddags van 2 tot 6 uren, en hịj kan de verzekering geven dat zij meer arbeids verrichten dan de werktaken bedragen, die door het goevernement zijn voorgeschreven. Zoo kent hij ook een man, die afkomstig is van de gewezen kolonisatie op Albina, een flinke kerel, thans in dienst van den heer Heylidy, die vrij wat werk verricht en toch gezond is. Maar wat is het geval geweest met die kolonisatie? Het werk dat de arbeiders daar verrichtten, was ondoelmatig, daarbij kwam het humeur van Kappler, dat veel tot de mislukking dier onderneming heeft bijgedragen.

Hij gelooft dat zulke menschen als hij op het oog heeft zeer goed kunnen werken in fabrieken en zelfs veldarbeid op plantaadjes kunnen verrichten, waartoe hij meent dat takwerk op stukken grond het beste is, mits zij voorzien worden van goede woningen en goed voedsel, welk laatste door hetgeen de jacht en visscherij oplevert zoo moeilijk niet te verschaffen is. Hij ziet er hoegenaamd geen bezwaar in om menschen uit Europa te krijgen, die voor den landbouw geschikt zijn en zelfs zwaar kunnen werken. Evenwel meent hij dat dit laatste hier niet noodig is en de arbeid lang niet zoo zwaar als in Europa behoeft te zijn.

De heer Dr. Juda kan zich met de bezwaren, die tegen den arbeid des morgens vroeg zijn ingebracht, niet vereenigen. Er is gezegd des morgens is het koud en te vochtig, dus ongezond, dan kunnen zij niet werken; des middags is het weêr te heet, dan ook niet. Het moge dan al 's morgens wat koeler zijn dan des middags, maar wat beteekent dit bij het groot verschil in temperatuur van Enropa? Het eene oogenblik kan het dáár stikkend heet zijn en het volgende stat men somtijds te bibberen van kou. En toch zal er niemand zijn die zegt dat het in Europa ongezond is. Hịj kent eene plaats in Ober-Beijeren alwaar des morgens koude snerpende winden waaien die over de besneeuwde bergtoppen heen strijken en toch kan hij verzekeren dat de menschen daar zeer gezond zijn. De dauw is niet ongezond om in te ademen; zij is dit wel wanneer de kleederen nat worden en men daarin blijft en stil staat. Miasmata zijn zoowel bịj dag als bị nacht aanwerig; deze stoflen 
bevinden zich in de lucht; is de inademing daarvan des morgens ongezond, dan zal dit ook 's middags wel het geval zịn. In de Oost zijn ook koudere streken, maar dit zijn juist de gezondste.

De heer Bosch Reitz erkent dat vele bezwaren, die hịj alsnog tegen eene kolonisatie met Europeanen in Suriname had, door de vorige sprekers zijn uit den weg geruimd. Indien hịj de bedoeling van den heer Abendanon wel begrepen heeft, dan kan hij zich in de hoofdzaak daarmede vereenigen. Hị is er zeer vóór Europeesche kolonisten voor de plantaadjes, om aldaar als ambachtslieden te werken, te laten uitkomen. Wat evenwel den grooten landbouw betreft, zoo verwacht hị daarvan geen goede resultaten; hij gelooft dat Europeesche boeren in het open veld werkende, te veel zullen lijden aan ziekten, die ontstaan zullen door de zware regens die hier vallen en wartegen zij zich niet beveiligen kunuen. Immers men kan geen enkelen dag bijna uitkiezen, waarop het niet regenen zal. Hij rekent dus wat den grooten landbouw aangaat volstrekt niet op Europeesche landverhuizers.

De Voorzitter zegt geheel in de overtuiging van den heer Bosch Reitz te deelen. Ook hij is van gevoelen dat Europeesche kolonisten niet in de aankweeking onzer stapelproducten kunnen voorzien. Dit wil echter niet zeggen dat hij geheel eene zoodanige kolonisatie verwerpt, integendeel heeft hij daarop binnen zekere grenzen ook zijne hoop gevestigd, en zou wel-wenschen dat voor den zoogenaamden kleinen landbouw op eene gezonde plaats eene proef genomen werd. Maar om verder te gaan, om daardoor te willen voorzien in het gebrek aan werkkrachten op de plantaadjes, daar is hịj ten stelligste tegen.

De heer Bosch Reitz wil nog doen uitkomen dat, wanneer die menschen op zich zelven worden gelaten, dat wil zeggen, indien zịj zoowel het werk als den tijd om aan den arbeid te gaan zelf kunnen uitkiezen, men dan ook naar zijn gevoelen goede resultaten van hen voor fabriekarbeid op plantaadjes kan verwachten.

Voor het overige zou hịj echter al die theoretische beschouwingen gaarne door iets meer practisch willen vervangen zien. Want is thans, in den toestand waarin de kolonie nu verkeert, 
wel met kans op goed succes aan kolonisatie te denken? Immers neen, op grond dat er geen geld is en kolonisatie noodzakelijk groote geldelijke opofleringen vereischt. Wie zal die kosten dragen? De kolonie? Het moederland? Ieder die met den tegenwoordigen toestand eenigzins bekend is zal het antwoord gereedelijk vinden. $\mathrm{Om}$ die reden gelooft hij dat het bespreken van Europeesche kolonisatie op het oogenblik geene practische resultaten oplevert. Later kan het zijn nut hebben, maar thans wordt daarmede niet voorzien in den arbeidsnood waarin wij tegenwoordig verkeeren.

De heer Abendanon gelooft niet gelukkig te zijn geweest in de duidelijke ontwikkeling zijner denkbeelden, ten minste hij meent dat zijne gezegden niet naar de juiste bedoeling zijn opgevat. Wat hij heeft willen zeggen is kortelijk dit:

Dat hij ook voor eene kolonisatie met Europeanen is, maar dat zulks op het oogenblik niet uitvoerlijk is, omdat er geene middelen zijn. Waren deze voorhanden, dan acht hij 'de zaak allezins mogelijk en voegt er bij, dat vele duizenden Europeanen gelukkig zouden zijn, indien zij als boeren en arbeiders op de plantaadjes konden worden geplaatst. Maar zooals reeds is aangemerkt, er zijn geen middelen; het zou tonnen gouds kosten. Evenwel gelooft hij, dat het toch op eene kleine schaal, geleidelijk aan, zou kunnen gelukken en de middelen daartoe niet zoo kostbaar en veel omvattend behoeven te zijn, waardoor zelfs de kans van welslagen grooter wordt. Van den aanvoer van Europeesche landbouwers verwacht hij groote verbeteringen in de kultuur; hoe eerder dit geschieden kan, des te beter zal het voor de kolonie zijn.

De heer de Granada zegt dat het zijne meening niet was, dat Albina reeds de kolonisatie-kwestie had beslist; hij heeft door die zaak aan te halen slechts een feit willen doen spreken, waarvan hij zelf ooggetuige is geweest.

Ten aanzien der kosten die tot het vestigen van een boerengezin, zooals voor huis-, landbouwgereedschappen enz. noodig zijn, had hij ook eene raming ontvangen, welke echter de door den heer Sander opgegeven som van $f 3000$. - aanmerkelijk overschrijdt.

De heer Sander licht zijne vorige rede breeder toe en zegt 
dat het zijne bedoeling niet was om eene Europeesche kolonisatie op groote schaal tot stand te brengen, maar wel geleidelijk aan en in het klein, zoodat de aankomenden eerst geplaatst worden bij alhier reeds gevestigde kolonisten. Hij meent dat daartoe niet zulke enorme middelen noodig zijn als men zich gewoonlijk voorstelt, terwijl die wijze beter is om zich aan het klimaat te gewennen en bekend te maken met de eigenaardigheden van het land en zijne kultuur. Werd eene kolonisatie op die wijze beproefd dan zou er alleen geld voor een huis noodig zijn; het overige zouden zij onder elkander kunnen vinden.

De heer Coster meent, nu er gesproken wordt over eene kolonisatie met Europeanen, het goed is geen bloote theorien te verkondigen, maar zooveel mogelijk bewijzen uit de ervaring bij te brengen, dat Europeanen hier werken kunnen. Het beste bewijs dat hij leveren kan is van zich zelven. Zijne ouders waren beiden Europeanen, die hem in het geheel niet hebben opgebracht om zoo te zwoegen, als hij later heeft moeten doen. Hij heeft hard gewerkt en dat niet alleen onder dak, maar ook buiten in het veld. Toen hij zijn loopbaan als blankofficier begon, heeft hij meer dan eene week achter elkauder spel gehoudeu. 's Morgens vroeg, terwijl de dauw hem bevochtigde, zoowel als bij de grootste hitte des middags moest hij naar het veld en hij is er gezond bij gebleven en sterk tegen in geworden. In het begin werd hij ook ziek, maar dit kwam dewijl hij in zijne jeugd niet tot werken was groot gebracht. In lateren tijd moest hij in het belang van zijnen houthandel veel reizen en heeft toen verschillende streken der kolonie bezocht: hij kan gerust zeggen bijna acht jaren in de binnenlanden te hebben doorgebracht. Hij is wel is waar dikwijls ziek geweest; maar indien hij van der jeugd af aan werken ware gewend, dan zou hij ook beter aan die vermoeinissen hebben weerstand geboden. Op de vraag dus: kunnen Europeesche kolonisten hier aarden, is zijn antwoord: ja, maar niet om in de rietgronden te arbeiden, dewijl het daarbij vereischt wordend delfwerk voor Europeanen ondoenlijk is. Voor de banannenteelt en cacaokultuur meent hij dat zij volkomen geschikt zijn, vooral wanneer zij op zich zelven kunnen arbeiden. Maar, zooals gezegd is, goed eten en behoorlijke huisvesting zijn voor hen eene hoofdzaak. 
De Voorzitter verklaart dat hị den heer Coster met genoegen heeft gehoord en dat het zeker wetenswaardig is wat hij heeft medegedeeld, vooral daar het eigene ondervinding is die hem doet spreken. Maar is dit nu wel een afdoend bewijg voor de waarheid der stelling dat Europeanen bij zwaren arbeid in een tropisch klimaat gezond kunnen blijven? Is door het voorbeeld, dat zooeven geschetst is, nu genoegzaam geconstateerd dat eene Europeesche kolonisatie slagen zal? De heer Coster schijnt van een ijzersterk gestel te zijn en daaraan kan het worden toegeschreven, dat hij bij al die geleden ontberingen en doorgestane vermoeinissen er zoo goed afgekomen is. Maar Spr. is nog volstrekt niet overtuigd dat dit op Europeanen in het algemeen van toepassing zoude zijn.

De heer Bosch Reitz beweert toch een voorbeeld te kunnen bijbrengen dat Europeesche kolonisten in Suriname van geslacht tot geslacht kunnen blijven voortbestaan. Hij heeft hier de Israëlieten op het oog, deze zijn reeds langen tijd inwoners der kolonie en toch niet ontaard; zij bestaan nog even krachtig en hịj gelooft in geen minder aantal dan voorheen. Het blijkt dus hieruit dat het Surinaamsch klimaat voor den Europeaan niet vijandig is. Maar eene voorwaarde is voor hun bestaan noodig. Zij moeten den tijd en de soort van arbeid zelven kunnen uitkiezen.

De heer Dr. Juda is het niet geheel met den vorigen spreker eens; hij meent dat de tịj, wanneer de Europeesche kolonisten aan den arbeid moeten gaan, wel degelijk bepaald moet zijn, opdat zijj gedurende het koelste van den dag zouden arbeiden en niet bij de groote hitte van het middaguur. De nieuw aangekomenen moeten niet aan zich zelven overgelaten worden en vooral die uit den minderen stand, die evenals de kinderen leiding behoeven.

Ook is hịj tegen eene te spoedige overbrenging van kolonisten, om de eenvondige reden, dat de kolonie er thans ongeschikt voor is daar de uitoefening der geneeskunst allergebrekkigst is ingerigt. Het is vooral de geneeskundige politie die verbetering eischt; is deze eenmaal beter geregeld, dan kan eene proef worden genomen, anders niet. Hij is volstrekt tegen eene onvoorbereide kolonisatie: eerst moeten alle voorbereidende maatregelen genomen worden en dan eerst kan eene proef met 
kans op goed gevolg genomen worden. Want het is niet door theorie, maar door praktijk dat de mogelijkheid eener Europeesche kolonisatie in Suriname bewezen moet worden. Eene proefneming op kleine schaal, maar geheel ingericht zooals de wetenschap die voorschrijft, is hiertoe voldoende.

De heer Carstairs heeft met genoegeu de belangrijke discussiën gehoord. Hij was altijd van gevoelen dat eene kolonisatie met Europeanen mogelijk is.

Allen, die heden avond gesproken hebben, zijn die meening toegedaan. Hij erkent, na de bezwaren van Dr. Dumontier in de vorige vergadering gehoord te hebben, dat hij eenigzins huiverig geworden was eene proef te nemen, maar nu hij een ander deskundige gehoord heeft, welke die bezwaren in het geheel niet deelt en zich sterk voor het nemen eener proef verklaart, $\mathrm{nu}$ is hij geheel en al verzekerd dat het gelukken zal.

Er is vroeger gesproken over de kolonisatie van Kappler aan de Marowijne en over de oorzaken, die hare mislukkiug hebben te weeg gebracht. Dit geeft hem aanleiding, als een voorbeeld dat Europeanen hier zwaar kumnen werken, iemand aantehalen, die van die kolonisatie afkomstig is en bij hem goed bekend is. Hij bedoelt Klaiber, een houtwerker in Saramacca: deze man werkt twee malen meer dan een neger en is een sprekend bewijs hoe Europeanen niet alleen zwaren arbeid kunnen verrichten en daarbij gezond kunnen blijven, maar ook hoe zij door vlijt vooruit kunnen komen en zich tot welstand kumnen verheffen.

Voor het oogenblik wil hij echter het kolonisatie-vraagstuk laten rusten en zich liever bezig houden met de immigratiezaak, die tegenwoordig van veel grooter belang is. De vraag, die thans zoo velen bezig houdt, is: hoe kunnen wij immigranten bekomeu om den grooten landbouw in stand te houden? Hiervan hangt de toekomst der kolonie af. Slechts door het aanvoeren van immigranteu in voldoendeu getale voor de plantaadjes, kan de kolonie weder tot haren vorigen bloei geraken Eerst moet de kolonie worden gereleveerd, alvorens aan kolonisatie kan worden gedacht. Het bevorderen van de immigratie moet dus tot het hoofdpunt onzer beschouwingen worden gemaakt. $\mathrm{H}_{\mathrm{j} j}$ meent dat dit geheel in den geest is van de bedoelingen des Instituuts en leest, als een bewijs hoezeer dit genootschap belang stelt in de immigratie-kwestie, een der vragen voor, die daarover voor West.Indie zijn uitgeschreven. 
Alhoewel hij dus het voorstel van den heer Abendanon goedkeurt, vindt hij de behandeling van het onderwerp der immigratie dringender en geeft dus in overweging om thans dit punt ter sprake te brengen.

De heer Coster acht het in het belang der kolonie, niet te zwijgen, nu hare teederste belangen worden ter sprake gebracht. De heer Scheltema had hem vroeger ook herhaaldelijk verzocht iets over hetgeen hij in de kolonie ondervonden heeft te schrijven en in het licht te geven en hij had daaraan eindelijk toegegeven door hem eene beschrijving zijner reizen en eene verhandeling over de boschnegers toetezenden. Hịj heeft dit gedaan om de kennis over de kolonie uittebreiden: hoe meer daarover kennis wordt verspreid, hoe beter het met kolonisatie zoowel als met immigratie zal gaan. Hij acht beiden met elkander verbonden en wenscht dus kolonisatie tegelijk met immigratie te doen plaats hebben. Immigranten voor de suikerkultuur en Europeesche kolonisten voor de cacao, koffie en banannen. Hij gelooft dat wij dit tot het hoofdpunt der beschouwingen moeten maken.

De heer Carstairs releveert zijn vroeger gezegde en zegt, dat zeer zeker kolonisten voor de andere soorteu van kultuur kunnen gebezigd worden, maar dit is in ieder geval nog slechts eene bespiegeling. Suriname kan daarop niet wachten. Het is nu geen tijd om proeven te nemen; de kolonie moet dadelijk geholpen worden en dit vooral, omdat zij door suiker hoofdzakelijk moet bestaan. Hij oppert dus andermaal de vraag of het niet doelmatiger is kolonisatie te laten rusten en immigratie aan de orde te stellen.

De heer Bosch Reitz gelooft dat de meerderheid het eens is, dat de kolonie door suikerkultuur moet bestaan en dat daartoe inmigranten noodig zijn. Er is lang over kolonisatie gesproken en hij is er eeu voorstander van. Maar hij wenscht op praktisch terreiu te komen. De heer Jurla heeft gezegd, dat de geneeskundige verpleging slecht is en dat Suriname voor eene Europeesche kolonisatie ongeschikt is, zoolang deze niet beter geregeld is. Van den heer Sander heeft hij gehoord, dat de boeren bij de stad meer menschen willen hebben; zou dit nu niet kumnen plaats hebben; zou men geen proef kuınen nemen om kolonisten te doen uitkomen en te plaatsen bij de boeren, 
en zou het niet goed zijn dit punt ter sprake te brengen bij het bestuur in het Moederland?

De heer de Granada zegt dat de heer Coster een punt heeft over het hoofd gezien. Met eene kolonisatie op de wijze zooals door den heer Sander is voorgesteld, kan hij zich zeer goed vereenigen. Voor den kleinen landbouw en de veeteelt gelooft hij dat zij allezins gelukken zal. Eene tewerkstelling van Europeanen op de plantaadjes als ambachtslieden voor den fabriekarbeid lacht hem evenzeer toe. Maar hij gelooft niet dat de proef gelukken zal om hen als arbeiders op cacao-, koffie- en banannenplantaadjes te plaatsen. Hij heeft dit wel is waar van meer dan eene zijde hooren beweren, maar bij hem bestaan bedenkingen, die hij gaarne bevredigend wenschite opgelost te zien. De vraag is namelijk bij hem opgekomen of de Europeesche . landbouwer van het dagloon bestaan kan, dat op de plantaadjes gegeven wordt en of hij daarvan tevens zijn gezin kan onderhouden? Ook een tweede even gewichtige vraag: waar moeten hunne kinderen op school gaan? Immers met enkele uitzonderingen zijn er geen scholen in de districten. Sektenscholen, zooals die der Moravische broeders en Roomsch-Katholijken vindt hij ondoelmatig; deze kunnen dus bij de beantwoording der vraag gerust buiten aanmerking blijven.

De Voorzitter zegt dat hij geen tegenstander is van Europeesche kolonisatie, zooals uit de vorige notulen genoegzaam gebleken is; hij is nog meer een voorstander van die zaak gewordeu, na hetgeen hij nu gehoord heeft. Maar die te veel wil op eens, komt gewoonlijk tot niets. Op dit oogenblik is het voornaamste het behoud der kolonie, in den zin van eene productieve rentegevende kolonie; en daartoe wordt immigratie vereischt. Dit punt is algemeen erkend; hij behoeft daarover thans niet uitteweiden; het is erkend door de Koloniale Staten, door het hoofd van het Bestuur alhier, door deskundigen in Europa, waaronder mannen als Schimpf, van Lansberge, van der Gon Netscher, Elzevier en zooveel anderen. Immigratie is de hoofdzaak, zonder die gaat de kolonie te niet. Indien men dus iets in het belang der kolonie wenscht te doen, dat men dan met immigratie beginne; door er kolonisatie bijtevoegen, verlangt men te veel op eens en komt uiets tot stand. Kolonisatie is wenschelijk, maar zij moet nog beproefd worden; 
immigratie daarentegen is dringend noodig en eene zaak van algemeene bekendheid die niet meer beproefil behoeft te worden. Terwijl hij zich nu wel kan vereenigen met het voorstel van den heer Abendanon om een ontwerp op zakelijke verhandeling te leveren over kolonisatie, wenscht hij de dringender immigratiezaak op eene meer praktische wijze te bevordereu en resumeert ziju voorstel aldus: dat eenige heeren worden uitgenoodigd een kort en zakelijk verslag over kolonisatie te ontwerpen en de middelen te beramen om tot eene behoorlijke uitvoering te komen; maar bovenal dat deze vergadering zich zonder tijdverlies wende tot het bestuur van het Koninklijk Instituut met het verzoek om ook van zijnentwege het voorstel, dat thans door vele ingezetenen aan Z. M. den Koning aangeboden wordt om immigratie van Staatswege, te ondersteunen. Hij is van oordeel, dat, wanneer het Instituut verzocht wordt om dit punt bij de Hooge Regering aan te bevelen, men dan juist doet, wat het bestuur vau dat Instituut verlangt, wat geheel in diens werkkring ligt. Een verslag omtrent immigratie in de Engelsche en Fransche kolonien acht hij minder noodig. $\mathrm{Hij}_{\mathrm{ij}}$ wenscht dus dat bij de pogingen, die van verschillende zijden worden in het werk gesteld om de immigratie te bevorderen, de leden des Instituuts in Suriname niet achterblijven, maar zich met een kort woord tot het Instituut wenden, om het verzoek, dat eene immigratie van Staatswege worde tot stand gebracht, te ondersteunen. Hị voorziet hiervan een resultaat, dat in zijne gevolgen heilzaam voor de kolouie kan zijn.

De heer Boscin Reitz zegt dat alles op dit oogenblik vau immigratie afhangt; deze zaak staat op deu voorgrond. Hij wil dus al hetgeen dezeu avond behandeld is zaâmvatten en daaruit het besluit trekken dat kolonisatie op het oogenblik niet doenlijk is.

De Voorzitter herhaalt dat immigratie zoo dringend is, dat hij het voorstel doet om ous zonder uitstel tot het Instituut te wenden met een verzoek in den geest als door hem opgegeven is en daarbij vooral te wijzen op het dringende dezer kwestie.

Dit voorstel vindt in de vergadering algemeenen bijval.

De heer Coster wil daar nog iets bijgevoegd hebben. Hij zegt dat immigratie noodzakelyj is voor de suikerkultuur, maar 
dat kolonisatie noodig is voor de cacao en andere takken van landbouw. De leden der Europeesche gezinnen kunnen allen voor den landbouw worden aangewend; klein en groot, mannen en vrouwen kunnen voor de verschillende werkzaamheden op de plantaadjes worden gebezigd en dus te zamen zooveel verdienen als voor een redelijk bestaan noodig is. Wanneer de immigratie dus niet op groote schaal kan plaats hebben, dan kunnen de immigranten alleen voor de suikerplantaadjes dienen, terwijl dan eene Europeesche kolonisatie zeer te stade zal komen om in de behoefte der andere plantaadjes aan arbeiders te gemoet te komen.

Hij stelt dus voor, het Instituut tevens in bedenking te geven om, wanneer die immigratie niet op groote schaal tot stand zal komen, alsdan zijne hulp voor eene Europeesche kolonisatie te willen verleenen.

De heer Carstairs zegt, dat immigratie de hoofdzaak is en men zich tot éene zaak bepalen moet; hij geeft de voorkeur aan immigratie boven kolonisatie.

De heer Bosch Reitz kan zich met het denkbeeld van den heer Coster wel vereenigen, maar niet om zich daarmede tot het Instituut te wenden. Dewijl er een besluit zal genomen worden, moet dit in bepaalden zin geschieden; men kan met geen twijfelachtig voorstel voor den dag komen en tot het Instituut zeggen : als gij de immigratiezaak niet op eene voldoende wijze bevorderen kunt, helpt ons dan met kolonisatie; dit gaat niet aan.

De Voorzitter zegt dat de vergadering het dus eens is om een besluit te nemen en dat hij met zijne medecommissarissen reeds over eene motie gesproken heeft, die hij thans aan het oordeel der vergadering onderwerpt:

De motie luidt aldus:

"De in Suriname gevestigde leden van het Koninklijk Instituut voor de Taal- Land- en Volkenkunde van Nederlandsch Indië;

Overwegende dat van eene spoedige en krachtige immigratie van arbeiders, het bestaan der kolonie Suriname afhankelijk is;

Overwegende, dat het gebleken is dat alle tot aanvoer van arbeiders zijdens particulieren en zijdens eener maatschappij aangewende pogingen te eenenmale onvoldoende zijn om in die volstrekte behoefte te voorzien;

Overwegende dat immigratie op voldoende wijze alleen moge3e Volgr. VI. 
lijk is, wanneer zij, evenals in de naburige Engelsche en Fransche kolonien eene Regeringszaak worde;

\section{Besluiten:}

Het Bestuur van het voornoemd Instituut dringend te verzoeken, met alle te zijnen dienste staande middelen, de Immigratie van Staatswege te bevorderen."

De heer Abendanon verklaart dat niemand grooter voorstander van eene immigratie van Staatswege is, dan hij. Hij is ten volle overtuigd, dat geen particulieren, geene maatschappij voor immigratie kan doen, wat de Staat vermag, omdat deze middelen bezit, waarover gene niet kan beschikken. Hij is het dus geheel eens, dat het in het belang der kolonie wenschelijk is, dat de Regeering zich met de immigratie meer rechtstreeks inlate, dan tot nu toe het geval is. Tot zooverre kan hij zich dus geheel met de motie vereenigen; maar het daarin voorkomend gezegde, dat de pogingen der immigratie-maatschappij onvoldoende zijn gebleken, kan hij volstrekt niet goedkeuren en acht hij zich verplicht als agent van die maatschappij daartegen op te komen.

$\mathrm{Om}$ over hare handelingen een oordeel te kunnen vellen, moet mon met alle omstandigheden bekend zijn; en daar hij veronderstelt dat dit met het meerendeel der vergadering niet het geval is, zal hij de vrijheid nemen daaromtrent eenige bijzonderheden mede te deelen in de hoop, dat men dan wellicht van dit oordeel terug komen zal.

Hij wenscht te beginnen met te zeggen, dat eene der groote verdiensten van de immigratiemaatschappij deze is, dat zij den weg geopend heeft voor landverhuizing naar Suriname. Men is niet genoeg op de hoogte om te kunnen beoordeelen met hoeveel bezwaren zij te kampen heeft gehad, hoeveel rampen zij heeft ondervonden, alvorens het zoo ver gebracht is. In het begin moest de maatschappij de plaatsen zoeken, van waar men immigranten bekomen kon; en hoeveel moeite er ook is aangewend, is het nog maar alleen met China mogen gelukken. Zij heeft echter den moed niet opgegeven om ook andere bronnen geopend te krijgen en, alhoewel de bezwaren, waarmede zij te worstelen heeft, talrijk zijn, zoo gelooft hij op goede gronden, dat zij toch in het eind overwinnen zal.

Reeds met een enkel woord heeft hij gesproken dat de maatschappij ook het oog op andere plaatsen dan China gevestigd 
heeft en als zoodanig kan hij Hindostan noemen. Sedert de laatste jaren is de matschappij bezig om dit land voor eene immigratie van vrije arbeiders naar Suriname te openen; hij kan er bijvoegen dat men reden heeft te gelooven, dat het eindelijk gelukken zal en er een traktaat desbetreffende met Engeland zal gesloten worden, zoodat men niet meer uitsluitend van China afhankelijk zal zijn. Hij vertrouwt dat deze mededeeling met belangstelling zal vernomen worden en bewijzen zal dat men niet stil gezeten heeft. Hij is van zijn kant volkomen overtuigd, dat de immigratie-maatschappij voldoende heeft gewerkt en gedaan heeft wat met mogelijkheid gedaan kon worden en dat zij dus het oordeel niet verdient, waarvan in deze motie sprake is Niemand liever dan hij zou zien dat de immigratie eene regeeringszaak wierd en zoozeer is hij van het groot belang, dat de kolonie daarbij heeft, doordrongen, dat hij niet aarzelt aan het goevernement zonder loon zijne diensten in dezelfde betrekking aan te bieden, als waarvoor hij nu rijkelijk bezoldigd wordt. Doch hij verzoekt uit het besluit te lichten de woorden: dat de pogingen der maatschappij te eenenmale onvoldoende gebleken zijn.

De Voorzitter dankt den heer Abendanon voor de belangrijke mededeeling, die hij gelooft dat met evenveel genoegen door de vergadering vernomen is. Hij gelooft de verzekering te kunnen geven dat niemand aan de belangstelling van den hee Abendauon in deze aaugelegenheid getwijfeld heeft en wanneer hij daarnaar afmeten kan de belangstelling van het hoofdbestuur der immigratie-maatschappij dan is het niet te betwijfelen of zij doet al wat haar mogelijk is. De motie heeft dan ook niet de strekking dit te betwijfelen. Integendeel, men erkent gaarne de pogingen welke de maatschappij aanwendt; maar, wanneer men toch ziet, dat op dit oogenblik de behoefte aan arbeiders zoo groot blijft en er niet in wordt voorzien; - dat de pogingen der maatschappij, door welke oorzaak ook, blijkbaar te kort schieten en zij onmachtig is om op eene voldoende wijze arbeiders aantevoeren, dan vraagt hij of het wel te veel is gezegd, dat hare pogingen zijn gebleken onvoldoende te zijn.

De heer Abendanon zegt, dat de mannen die ons moeten steunen in de immigratiezaak, dezelfde zijn als die van de maatschappij. Onze stem moet weêrklank vinden; laat ons dus 
vermijden om dergelijke passages op te nemen, die misschien mannen zullen krenken, die door hun geld zoowel als door hunne talenten de zaak hebben tot stand gebracht. Door de besproken passage in het besluit der vergadering weg te laten, zal het dezelfde kracht behouden en meer medewerking in Nederland ondervinden, dan wanneer het onveranderd aangenomen wordt.

De Voorzitter meent dat in de aangevallen passage voor niemand eene krenking gelegen is en leest andermaal den considerans der motie voor.

De heer Mr. Bosch Reitz stelt voor om de clausule te veranderen en uit de voorgestelde motie te lichten de woorden: "en zijdens eener maatschappij." Hij meent dat daardoor de zaak dezelfde beteekenis blijft behouden, maar niet zoo bepaaldelijk op de immigratie-maatschappij gewezen wordt.

De heeren Carstairs en Dr. Juda zijn tegen dit voorstel en willen juist de maatschappij aanvoeren om aan den zin, dat particuliere pogingen in deze aangelegenheid onvoldoende zijn en dus de Staat bij moet springen, meer kracht te geven.

De heer Sander meent, dat er, zooals de motie thans luidt, wel iets hinderlijks in is en stelt tot wegneming daarvan voor niet in den tegenwoordigen tijd te spreken en in te lasschen de woorden: "tot nu toe."

De Voorzitter wenscht niet dat de motie iets inhoude wat iemand zou kunnen hinderen, maar wat men zeggen wil, dat, wat men meent, dat moet men toch zeggen.

Alhoewel hij in de motie niets krenkends ziet, wat iemand zich zou kunnen aantrekken, wil hij daaromtrent echter gaarne zich aan het oordeel der vergadering onderwerpen.

De heer Carstairs zegt zelf aandeelhouder in de immigratiemaatschappij te zijn en dat hij onlangs nog om inlichtingen betreffende den stand der zaken heeft gevraagd, dewijl de maatschappij niets van zich hooren liet. Wat de immigratie uit Hindostan betreft, waarover ter loops door den heer Abendanon gesproken is, zoo betwijfelt hij of dit door deze maatschappij tot stand zal komen, omdat het hem bekeud is, dat lord Russell 
zich indertijd heeft uitgelaten, dat Engeland nooit eene immigratie van arbeiders uit dat land toe zal laten door middel van particuliere ondernemingen.

De heer Abendanon zegt slechts weinig aandeelen in de Surinaamsche immigratie-maatschappij te hebben, maar dat hij daarentegen veel in haar belang heeft gewerkt. Hij vermeent dat de reden waarom het Britsch goevernement tot dusverre aan particulieren geweigerd heeft om arbeiders uit Hindostan te voeren, hoofdzakelijk gelegen is in de retourpassage, waarvoor geen behoorlijke waarborgen werden gesteld.

De Voorzitter vraagt of die reden wel juist is, dewijl hij meent dat de waarborg voor vrijen terugtocht van landverhuizers naar het land hunner herkomst in de immigratie-verordening voorgeschreven is.

De heer Abendanon zegt dat hij genoegen neemt met de motie, indien zij gewijzigd wordt overeenkomstig het voorstel van den heer Bosch Reitz.

$\mathrm{Na}$ nog eenige korte discussien wordt dat voorstel eenigzins gewijzigd aangenomen.

Het voorstel, thans luidende:

"De in Suriname gevestigde leden van het Koninklijk Instituut voor de Taal- Land- en Volkenkunde van Nederlandsch Indie;

"Overwegende dat van eene spoedige en krachtige immigratie van arbeiders het bestaan der kolonie Suriname afhankelijk is;

"Overwegende, dat het gebleken is dat alle tot aanvoer van arbeiders door particuliere ondernemingen aangewende pogingen, te eenenmale onvoldoende zijn om in die volstrekte behoefte te voorzien;

"Overwegende, dat immigratie op voldoende wijze alleen mogelijk is, wanneer zij evenals in de naburige Engelsche en Fransche kolonien, eene Regeringszaak worde;

"Besluiten :

"Het Bestuur van het voornoemd Instituut dringend te verzoeken, om met alle te zijnen dienste staande middelen, de immigratie van Staatswege te bevorderen."

wordt daarna met algemeene slemmen aangenomen. 
De Voorzitter stelt thans het onderwerp kolonisalie an de orde. Ten einde ook hierin tot een practisch resultaat te komen, wil hij van zijn kant ondersteunen het straks geopperde voorstel om een beknopt en zakelijk verslag over dit onderwerp zamen te stellen, waarin vooral op de ervaring gewezen wordt. Indien twee of drie heeren zich daarmede wilden belasten, zou dit zeer veel nut kunnen stichten.

De heer Bosch Reitz vereenigt zich met dit voorstel en zou gaarne zien, dat de heer Dr. Juda een dergenen was, die dit op zich zouden willen nemen.

De Voorzitter stelt voor, de commissie voor bedoeld verslag zamen te stellen uit de heeren Coster, Abendanon, Sander en Juda. Met algemeene stemmen wordt dit voorstel gòedgekeurd. Genoemde heeren verklaren bereidwillig dit mandaat aan te nemen.

De heer Abendanon wenscht de commissie uit te breiden door medebenoeming van den heer Bosch Reitz. Ook dit voorstel wordt bij acclamatie goedgekeurd.

De heer Bosch Reitz verzoekt wegens te veel werkzaamheden van de commissie te worden verschoond, maar geeft echter op aandrang der vergadering toe en neemt de benoeming aan.

De Voorzitter heeft de aandacht der vergadering nog op iets te vestigen. Hij leest eene passage voor uit het verslag van den staat en de werkzaamheden gedurende het instituutsjaar 1866 vermeld op blz. 12 en 13 van de Bïdragen in het 2e deel $1_{\mathbf{e}}$ stuk over 1867 , onmiddellijk West-Indie betreffende. Hij doet daarbij een beroep op de kenuis en medewerking der leden in Suriname gevestigd, waarbij hij met genoegen op het goede voorbeeld wijst dat door den heer van Dissel gegeven wordt, van wien is ingekomen eene bijdrage getiteld: "Eenige opmerkingen omtrent den sloffelïken toestand van het eiland Curaçao;" die bestemd is om in het tijdschrift van het Instituut te worden opgenomen.

Op voorstel van den heer Abendanon, betuigt de vergadering aan den Voorzitter en de Commissarissen haren dank voor hetgeen door hen in het belang der kolonie en van het Instituut 
is verricht, waarop de vergadering door den Voorzitter gesloten wordt.

\section{VERGADERING VAN 16 JUNI 1868.}

GEHOUDEN TE PARAMARIBO.

Tegenwoordig: de heeren Mr. E. A. van Emden (Voorzitter), F. Carstairs, S. Soesman Jr., Dr. J. J. Juda, J. H. A. W. Bn. van Heerdt tot Eversberg, Dr. S. van Dissel, Dr. J. Sander, Mr. G. J. A. Bosch Reitz, S. Abendanon, A. H. de Grenada, Mr. B. E. Colaço Belmonte, J. van Praag en A. M. Coster.

De Voorzitter opent de vergadering en verwelkomt de nieuw benoemde ter vergadering aanwezige leden. Vermits de Secretaris, de heer J. F. A. Cateau van Rosevelt, wegens ambtsplichten, afwezig is, wordt de voorlezing der notulen van de vorige vergadering tot nader uitgesteld.

De Voorzitter herinnert het in de laatste vergadering over Immigratie verhandelde, en leest den brief voor die naar aanleiding van het toen genomen besluit, door commissarissen van het Instituut is geschreven; alsmede het daarop ontvangen antwoord dd. Mei jl. $\mathrm{n}^{0} 714$, en zegt dat de tegenwoordige vergadering belegd is, opdat de leden kennis van dat antwoord zouden nemen.

De leden zeggen met genoegen van dat antwoord kennis te hebben genomen.

De Voorzitter uit den wensch dat de commissie uit de leden benoemd ter indiening van een verslag over kolonisatie spoedig gereed zal zijn, als wanneer hij zich haasten zal de leden weder bijeen te roepen. 
De heer Abendanon, lid dier commissie, geeft te kennent dat alle bouwstoffen gereed zijn, en dat hij hoopt dat binnen veertien dagen het rapport uitgebracht zal kunnen worden.

De Voorzitter deelt mede dat nog van den heer van Dissel, wien hij daarvoor dank zegt, - ter inzending aan het Instituut ontvangen zijn twee bijdragen, als :

10 Eenige bijzonderheden omtrent het eiland Bonaire.

2o Uitstap van Curaçao naar Maracaibo in October en November 1860, alsmede ten uitstap van Maracaibo naar Sanfré de Cucuta in Nieuw Granada of de Vereenigde Staten van Columbia in Augustus 1861.

De Voorzitter sluit de vergadering. 